\title{
Communication
}

\section{Comparative Proteomics Analysis Reveals Unique Early Signaling Response of Saccharomyces cerevisiae to Oxidants with Different Mechanism of Action}

\author{
Prajita Pandey ${ }^{1,2,+}$, Khadiza Zaman ${ }^{3,+}$ (D) Laszlo Prokai $^{3}$ (D) and Vladimir Shulaev ${ }^{1,2, *}$ \\ 1 Department of Biological Sciences, College of Arts and Sciences, University of North Texas, \\ Denton, TX 76203, USA; PrajitaPandey@my.unt.edu \\ 2 Advanced Environmental Research Institute (AERI), University of North Texas, Denton, TX 76203, USA \\ 3 Department of Pharmacology and Neuroscience, University of North Texas Health Science Center, \\ Fort Worth, TX 76107, USA; Khadiza.Zaman@unthsc.edu (K.Z.); Laszlo.Prokai@unthsc.edu (L.P.) \\ * Correspondence: shulaev@unt.edu; Tel.: +1-940-369-5368 \\ + These authors contributed equally to this work.
}

Citation: Pandey, P.; Zaman, K.; Prokai, L.; Shulaev, V. Comparative Proteomics Analysis Reveals Unique Early Signaling Response of Saccharomyces cerevisiae to Oxidants with Different Mechanism of Action. Int. J. Mol. Sci. 2021, 22, 167. https://dx.doi.org/10.3390/ ijms22010167

Received: 25 November 2020 Accepted: 21 December 2020 Published: 26 December 2020

Publisher's Note: MDPI stays neutral with regard to jurisdictional claims in published maps and institutional affiliations.

Copyright: () 2020 by the authors. Licensee MDPI, Basel, Switzerland. This article is an open access article distributed under the terms and conditions of the Creative Commons Attribution (CC BY) license (https: / / creativecommons.org/ licenses/by/4.0/).

\begin{abstract}
The early signaling events involved in oxidant recognition and triggering of oxidant-specific defense mechanisms to counteract oxidative stress still remain largely elusive. Our discovery driven comparative proteomics analysis revealed unique early signaling response of the yeast Saccharomyces cerevisiae on the proteome level to oxidants with a different mechanism of action as early as $3 \mathrm{~min}$ after treatment with four oxidants, namely $\mathrm{H}_{2} \mathrm{O}_{2}$, cumene hydroperoxide ( $\mathrm{CHP}$ ), and menadione and diamide, when protein abundances were compared using label-free quantification relying on a highresolution mass analyzer (Orbitrap). We identified significant regulation of 196 proteins in response to $\mathrm{H}_{2} \mathrm{O}_{2}, 569$ proteins in response to $\mathrm{CHP}, 369$ proteins in response to menadione and 207 proteins in response to diamide. Only 17 proteins were common across all treatments, but several more proteins were shared between two or three oxidants. Pathway analyses revealed that each oxidant triggered a unique signaling mechanism associated with cell survival and repair. Signaling pathways mostly regulated by oxidants were Ran, TOR, Rho, and eIF2. Furthermore, each oxidant regulated these pathways in a unique way indicating specificity of response to oxidants having different modes of action. We hypothesize that interplay of these signaling pathways may be important in recognizing different oxidants to trigger different downstream MAPK signaling cascades and to induce specific responses.
\end{abstract}

Keywords: oxidative stress; reactive oxygen species; antioxidants; global untargeted proteomics; TOR signaling; RAN signaling; MAPK cascade

\section{Introduction}

Oxidative stress indicates an imbalance between the production of reactive oxygen species (ROS) and a biological system's ability to detoxify ROS and repair the subsequent damage [1]. Multiple ROS, including hydrogen peroxide $\left(\mathrm{H}_{2} \mathrm{O}_{2}\right)$, hydroxyl radical $\left(\mathrm{OH}^{\bullet}\right)$, singlet oxygen, and superoxide anion $\left(\mathrm{O}^{\bullet-}\right)$, are produced in biological systems and damage cellular components, including DNA, proteins, lipids, and carbohydrates [2] Cells constantly generate ROS in the mitochondria, endoplasmic reticulum (ER), plasma membrane and cytoplasm during aerobic respiration [3]. Under normal conditions, $1-2 \%$ of electrons leak from the mitochondrial electron transport chain and form a superoxide anion $\left(\mathrm{O}_{2}{ }^{\bullet-}\right)$ by cycling ubiquinol in the inner mitochondrial membrane [4]. ROS can overwhelm the cellular antioxidant defense system, either through an increase in ROS levels or a decrease in the cellular antioxidant capacity, leading to oxidative stress. Perturbations to the normal redox state of cells can result in toxic effects through ROS production leading to damage of cellular components [2]. Oxidative stress has been implicated in mediating programmed cell death (PCD) [5] and numerous diseases including cancer, cardiovascular 
disease, atherosclerosis, diabetes, arthritis, neurodegenerative disorders, and pulmonary, renal, and hepatic diseases [6]. Organisms have evolved a variety of specific mechanisms to protect themselves from the damaging effect of different ROS. The damage of a cell's macromolecular structures activates antioxidant defense pathways aimed to regulate cellular redox balance [7]. While in some cases a particular ROS species was linked to a specific pathology, the connection between individual ROS species and different diseases remains poorly understood. To complicate the story even more, a significant body of evidence suggests that in addition to cytotoxicity, ROS compounds have an important signaling role [6,7].

Despite the long history of oxidative stress research, very little is known about early signaling events involved in oxidant recognition that trigger a specific response. Early ROS signaling can manifest itself in changes in transcription, protein expression, post-translational modifications, and perturbation of metabolic networks. Global approaches, such as genomics, transcriptomics, proteomics and metabolomics, have enabled investigation of complex molecular networks involved in oxidative stress response [7]. Several studies have focused on quantifying global changes in transcriptome, proteome and metabolome following treatment with various oxidants.

Despite these studies shedding light on some regulatory responses, early signaling events in stress response that trigger specific defensive mechanisms to a given oxidant, which can make the difference between survival and death, are still largely unknown. This calls for a comprehensive study of the molecular mechanisms involved in survival, repair of damage, or cellular recovery from damage related to oxidative stress induced by oxidants with a diverse mechanism of action.

Saccharomyces cerevisiae is a useful eukaryotic model for studying various aspects of oxidative stress at biochemical, cellular, and molecular levels. The nature of stress factors in yeast, and the damage caused by the oxidative stress to nucleic acids [8], lipids [9], proteins [10], and other cell components are like higher eukaryotes. The primary defenses involved in the catabolism of ROS and the scavenging system is also similar to higher eukaryotes [11]. They acquire multiple $\mathrm{H}_{2} \mathrm{O}_{2}$ detoxifying enzymes, such as catalases, cytochrome $c$ peroxidase, glutathione peroxidases, glutaredoxins and peroxiredoxins, many in distinct cellular compartments, which makes it an advanced model for the analysis of oxidative stress [12]. Additionally, a completely sequenced genome, easy laboratory handling and the availability of a nearly complete collection of gene deletion mutants is a big advantage to the research [13]. They can be manipulated physiologically in different growth and environmental conditions [13].

The objective of our study is to determine early signaling events required for sensing different oxidants and triggering oxidant-specific defenses. Additionally, we aimed to identify distinct mechanisms corresponding to a particular oxidant. In efforts to delve into the distinct molecular mechanisms in oxidative stress response, we designed a comparative LC-MS/MS-based proteomic workflow relying on a hybrid mass spectrometer equipped with a high-resolution mass analyzer (Orbitrap) to find changes in the S. cerevisiae proteome after exposure to chemically diverse ROS generating agents with distinct mechanism of action: $\mathrm{H}_{2} \mathrm{O}_{2}$, menadione (superoxide-generating agent), cumene hydroperoxide (CHP, an aromatic hydroperoxide), and diamide (thiol oxidant).

\section{Results and Discussion}

\subsection{Changes in Global Proteome Expression Caused by Different Oxidants}

Oxidative stress can be induced by different oxidants with different molecular targets. It has been shown that cells have distinct mechanisms to maintain protection against different ROS utilizing different sets of oxidative-stress-response genes [14]. Several studies also show that different oxidants induce differential transcriptional, translational, and metabolic response [14,15], but the precise mechanism of sensing different oxidants and triggering oxidant-specific defenses remains unknown. 
Our label-free global quantitative proteomics analysis based on high-resolution mass spectrometry (Orbitrap) revealed that the yeast proteome responds to oxidants with different mechanisms of action. We identified important signaling cascades that are triggered as early as $3 \mathrm{~min}$ in response to stress. These early stress-responsive mechanisms may be very important to determine the fate of the cells after stress. To identify early changes in proteome induced by different oxidants, we used four diverse ROS generating agents with distinct mechanisms of action, including $\mathrm{H}_{2} \mathrm{O}_{2}$, menadione (superoxide inducer), cumene hydroperoxide (CHP, an aromatic hydroperoxide), and diamide (thiol oxidant).

The total number of proteins identified in each individual treatment is shown in Supplementary Table S2. Quantitative analysis identified 196 proteins that significantly changed their expression in response to $\mathrm{H}_{2} \mathrm{O}_{2}, 569$ proteins in response to CHP, 369 proteins in response to menadione and 207 proteins in response to diamide (Supplementary Table S3).

Moreover, comparison of response to different oxidants showed that each oxidant triggered a unique response on a protein level as early as $3 \mathrm{~min}$ post treatment with a set of proteins that respond only to each individual oxidant. Comparisons of unique and shared proteins between treatments are shown in Figure 1. Only 17 proteins were common across all four treatments, but many proteins were shared between two or three oxidants. CHPtreatment had largest number of unique regulated proteins (297) followed by menadione (66), $\mathrm{H}_{2} \mathrm{O}_{2}$ (33) and diamide (30) and A complete list of proteins is given in Supplementary Table S3.

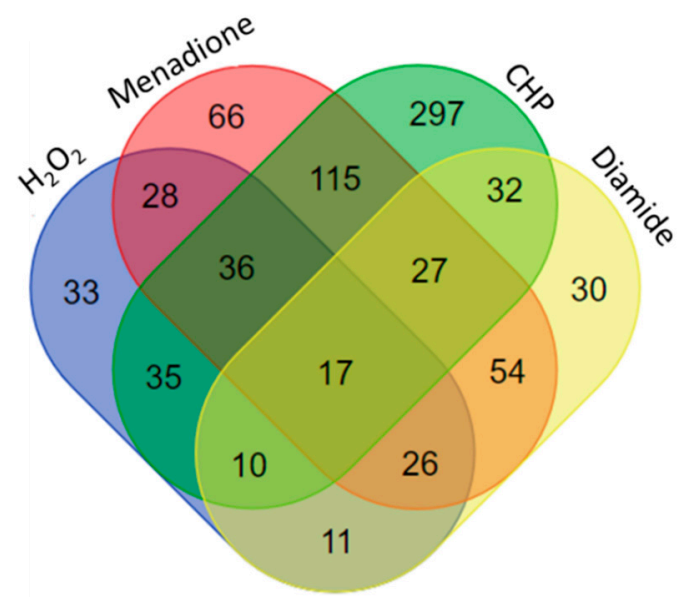

Figure 1. Venn diagram showing unique and shared proteins significantly regulated $(p<0.05)$ by $\mathrm{H}_{2} \mathrm{O}_{2}$, hydroperoxide $(\mathrm{CHP})$, menadione, and diamide 3 min post treatment. Data was analyzed using Proteome Discoverer 2.4 using label-free quantification relying on precursor ions of tryptic peptides based on high-resolution (Orbitrap) mass spectrometry.

\subsection{Major Regulatory Pathways Involved in Oxidative Stress Response}

The molecular and cellular functions most significantly impacted by different oxidants are summarized in Table 1. Several perturbed molecular and cellular functions were found to be shared between all four or fewer treatments, suggesting a varied extent of overlap in the oxidative stress response. This correlates with previous findings that there is overlap in stress response after treating S. cerevisiae with various oxidants [14]. Although some processes were similar amongst the four treatments, the overall associated molecular and cellular functions appeared to be different (Table 1). Our data indicate that the global early response to oxidative insult involves the activation of repair and survival mechanisms, which is not surprising (Table 1). The most significant molecular and cellular function in response to $\mathrm{H}_{2} \mathrm{O}_{2}$, diamide and menadione was cell death and survival, whereas gene expression was the most significant in response to CHP. Although yeast has a pool of antioxidants and pro-survival pathways protecting against ROS, these systems may fail in the case of sudden or prolonged insult by ROS [16], which impacts cell death and 
survival pathways. Drug metabolism and small molecule biochemistry were unique to $\mathrm{H}_{2} \mathrm{O}_{2}$, while DNA replication, recombination, and repair were unique to $\mathrm{CHP}$, and protein synthesis was unique to menadione. RNA post-transcriptional modification was regulated by all treatments, suggesting its importance in oxidative stress response. Recent studies have revealed post-transcriptional modifications as important biomarkers of ageing and age-related diseases [17].

Table 1. Top five molecular and cellular functions represented by Ingenuity Pathway Analysis ${ }^{\circledR}\left(\right.$ IPA $\left.^{\circledR}\right)$ using significantly regulated proteins identified by label-free quantitative proteomics performed in S. cerevisiae strains treated with the chosen four different oxidants. Asterisks (*) indicate unique molecular and cellular function.

\begin{tabular}{|c|c|c|c|}
\hline Treatment & Represented Process & $p$-Value Range & Number of Molecules \\
\hline \multirow{5}{*}{$\mathrm{H}_{2} \mathrm{O}_{2}$} & Cell Death and Survival & $4.39 \times 10^{-2}-3.63 \times 10^{-6}$ & 22 \\
\hline & Drug Metabolism * & $4.53 \times 10^{-2}-9.37 \times 10^{-6}$ & 4 \\
\hline & Small Molecule Biochemistry * & $4.53 \times 10^{-2}-9.37 \times 10^{-6}$ & 23 \\
\hline & RNA Post-Transcriptional Modification & $1.84 \times 10^{-2}-2.19 \times 10^{-5}$ & 7 \\
\hline & Molecular Transport & $4.53 \times 10^{-2}-5.60 \times 10^{-6}$ & 10 \\
\hline \multirow{5}{*}{$\mathrm{CHP}$} & Gene Expression & $1.88 \times 10^{-3}-2.09 \times 10^{-13}$ & 38 \\
\hline & RNA Damage and Repair & $2.64 \times 10^{-8}-2.09 \times 10^{-13}$ & 28 \\
\hline & RNA Post-Transcriptional Modification & $4.70 \times 10^{-4}-2.09 \times 10^{-13}$ & 39 \\
\hline & DNA Replication, Recombination, and Repair* & $2.60 \times 10^{-3}-1.15 \times 10^{-12}$ & 47 \\
\hline & Nucleic-Acid Metabolism & $3.72 \times 10^{-3}-1.15 \times 10^{-12}$ & 34 \\
\hline \multirow{5}{*}{ Menadione } & Cell Death and Survival & $2.78 \times 10^{-2}-1.67 \times 10^{-12}$ & 46 \\
\hline & Gene Expression & $2.39 \times 10^{-2}-2.46 \times 10^{-7}$ & 39 \\
\hline & RNA Damage and Repair & $2.21 \times 10^{-2}-2.46 \times 10^{-7}$ & 17 \\
\hline & RNA Post-Transcriptional Modification & $1.91 \times 10^{-2}-2.46 \times 10^{-7}$ & 18 \\
\hline & Protein Synthesis * & $1.33 \times 10^{-2}-1.69 \times 10^{-6}$ & 39 \\
\hline \multirow{5}{*}{ Diamide } & Cell Death and Survival & $2.17 \times 10^{-2}-1.50 \times 10^{-9}$ & 28 \\
\hline & Gene Expression & $2.17 \times 10^{-2}-1.04 \times 10^{-6}$ & 10 \\
\hline & RNA Damage and Repair & $6.86 \times 10^{-3}-1.04 \times 10^{-6}$ & 15 \\
\hline & RNA Post-Transcriptional Modification & $9.35 \times 10^{-4}-1.04 \times 10^{-6}$ & 14 \\
\hline & Molecular Transport & $2.17 \times 10^{-2}-2.50 \times 10^{-5}$ & 20 \\
\hline
\end{tabular}

Furthermore, IPA ${ }^{\circledR}$-based network analysis identified associated network functions regulated by different oxidants (Figure 2, Supplementary Table S4). The highest scoring associated network function with the largest number of molecules in response to $\mathrm{H}_{2} \mathrm{O}_{2}$ was cell death and survival, drug metabolism, small molecule biochemistry (Figure 2A). In response to $\mathrm{CHP}$, the highest scoring associated network functions were cellular assembly and organization, cell-to-cell signaling and interaction, reproductive system development and function (Figure $2 \mathrm{~B}$ ). In response to menadione, the highest scoring associated network functions were protein synthesis, cancer, cell death and survival (Figure 2C). In response to diamide, the highest scoring associated network functions were cell cycle, infectious diseases, cellular assembly and organization (Figure 2D). Both menadione and $\mathrm{H}_{2} \mathrm{O}_{2}$ had cell death and survival as top perturbed network functions. Not surprisingly, many of these pathways have been associated with oxidative stress [18-20]. Another important observation was downregulation of cytochrome $c$ oxidase in cell death and survival pathway in response to $\mathrm{H}_{2} \mathrm{O}_{2}$ and menadione. The cell death in yeast was linked to the release of cytochrome $c$ from the outer mitochondrial membrane to the cytoplasm, leading to disruption of oxidative phosphorylation [21]. 


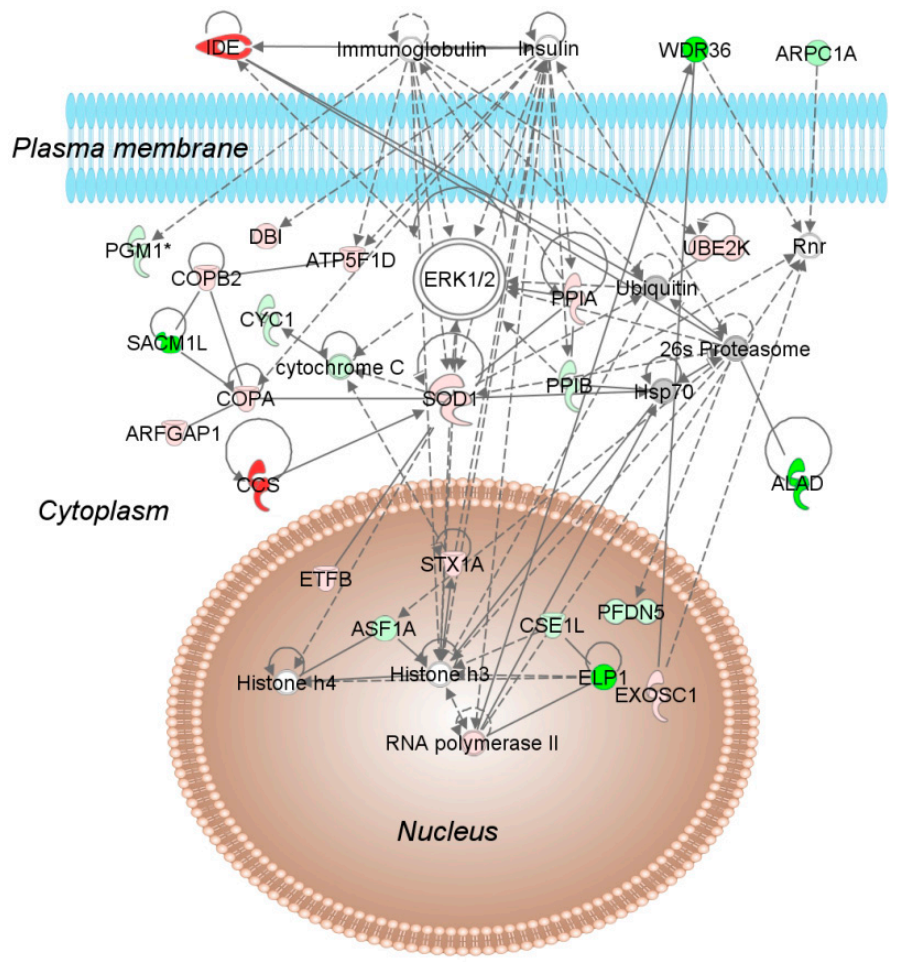

(A)

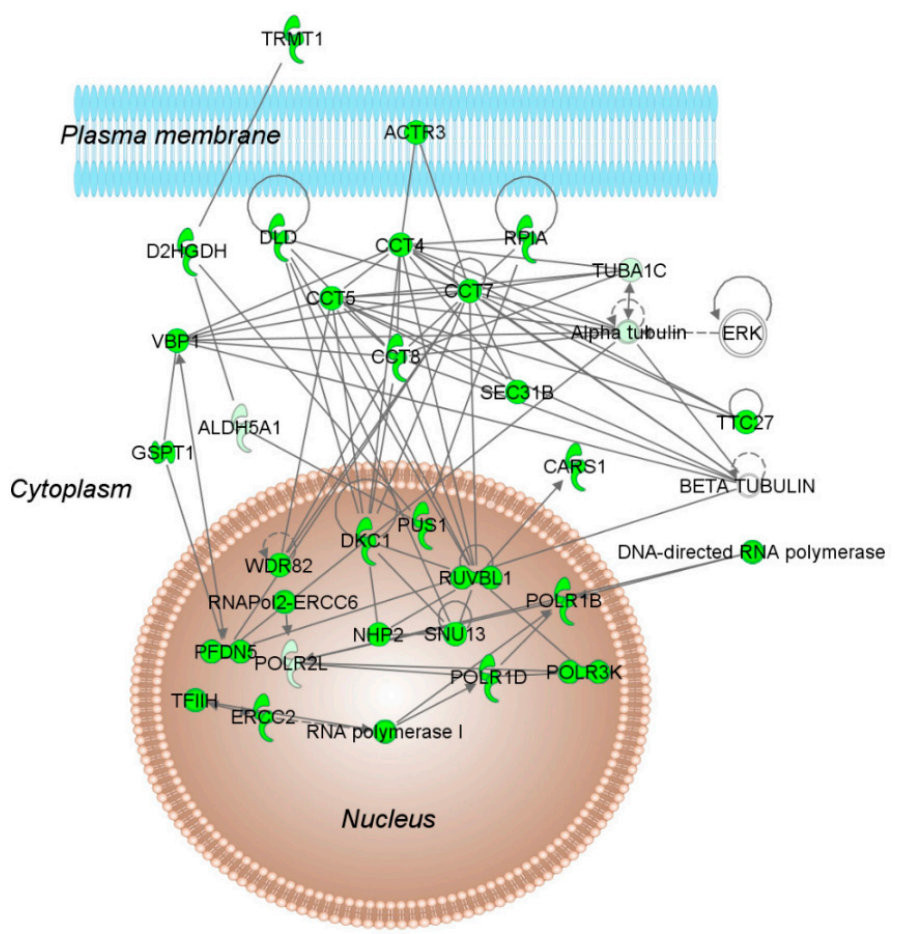

(B)

Figure 2. Cont. 


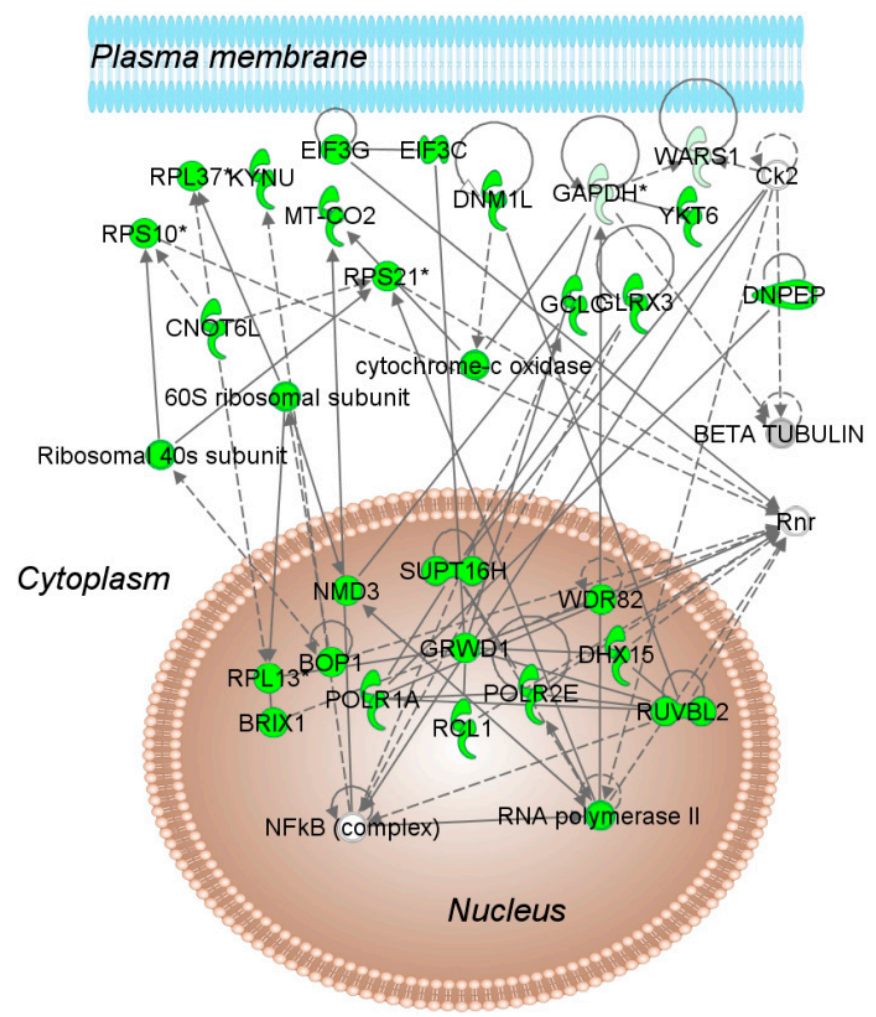

(C)

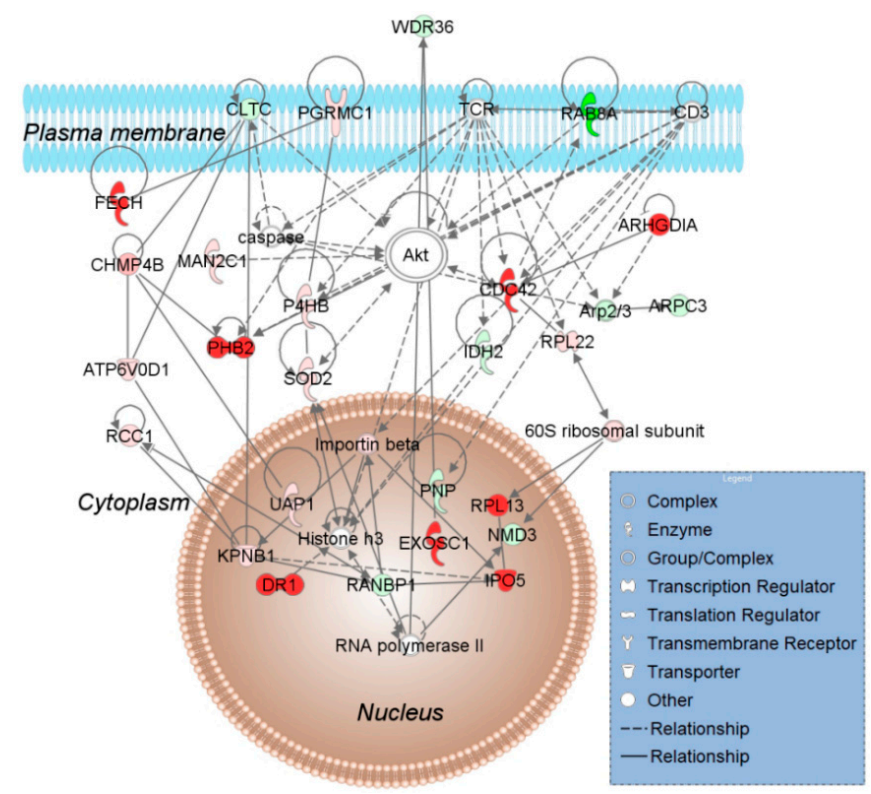

(D)

Figure 2. Top networks in S. cerevisiae response to oxidants at 3 min by $(\mathbf{A}) \mathrm{H}_{2} \mathrm{O}_{2}$ : cell death and survival, drug metabolism, small molecule biochemistry; (B) CHP: cellular assembly and organization, cell-to-cell signaling and interaction, reproductive system development and function. Top networks in S. cerevisiae response to oxidants at $3 \mathrm{~min}$ by $(\mathbf{C})$ menadione: protein synthesis, cancer, cell death and survival; and (D) diamide: cell cycle, infectious diseases, cellular assembly and organization. The shapes (see legend in blue box) represent molecular classes of the regulated proteins. In the network, red and green colors denote upregulation and downregulation in response to the four treatments, respectively. The intensity of color indicates the relative magnitude of fold change in the protein expression pattern. Solid and dashed lines represent direct and indirect interactions, respectively. 
Using IPA ${ }^{\circledR}$, we also interrogated canonical pathways significantly responding to oxidant treatment (Table 2). Similar to network functions, the four oxidants induced different sets of pathways, though some of the pathways were induced by multiple oxidants. Specifically, TOR (target of rapamycin) signaling, nicotinamide adenine dinucleotide (NAD) biosynthesis II (from tryptophan), glycogen degradation and regulation of eIF4 (eukaryotic initiation factor 4) signaling were unique in response to $\mathrm{H}_{2} \mathrm{O}_{2}$, glycine cleavage complex was unique in response to $\mathrm{CHP}$, RhoA signaling and heme biosynthesis II were unique in response to menadione, and sumoylation pathway, and urate biosynthesis/inosine $5^{\prime}$-phosphate degradation were unique to diamide-treated cells.

Table 2. Top five significant canonical pathways generated by IPA ${ }^{\circledR}$ using significantly regulated proteins identified by label-free quantitative proteomics performed in S. cerevisiae treated with the four different chosen oxidants. Asterisks $\left(^{*}\right)$ indicate unique molecular and cellular function.

\begin{tabular}{|c|c|c|}
\hline Treatments & Top Canonical Pathway & $p$-Value \\
\hline \multirow{5}{*}{$\mathrm{H}_{2} \mathrm{O}_{2}$} & Ran Signaling & $1.85 \times 10^{-5}$ \\
\hline & mTOR Signaling * & $4.79 \times 10^{-4}$ \\
\hline & NAD Biosynthesis II (from Tryptophan) * & $6.06 \times 10^{-4}$ \\
\hline & Glycogen Degradation I* & $6.06 \times 10^{-4}$ \\
\hline & Glycogen Degradation II * & $8.32 \times 10^{-4}$ \\
\hline \multirow{5}{*}{$\mathrm{CHP}$} & Protein Ubiquitination Pathway & $1.27 \times 10^{-12}$ \\
\hline & Ran Signaling & $1.36 \times 10^{-8}$ \\
\hline & eIF2 Signaling & $1.50 \times 10^{-8}$ \\
\hline & Remodeling of Epithelial Adherens Junctions & $6.96 \times 10^{-6}$ \\
\hline & Glycine Cleavage Complex* & $2.19 \times 10^{-5}$ \\
\hline \multirow{5}{*}{ Menadione } & Ran Signaling & $5.06 \times 10^{-10}$ \\
\hline & Remodeling of Epithelial Adherens Junctions & $3.48 \times 10^{-6}$ \\
\hline & RhoA Signaling * & $9.89 \times 10^{-6}$ \\
\hline & Heme Biosynthesis II * & $1.76 \times 10^{-5}$ \\
\hline & $\begin{array}{l}\text { Fc } \gamma \text { Receptormediated Phagocytosis in } \\
\text { Macrophages and Monocytes * }\end{array}$ & $2.28 \times 10^{-5}$ \\
\hline \multirow{5}{*}{ Diamide } & Ran Signaling & $3.81 \times 10^{-7}$ \\
\hline & Protein Ubiquitination Pathway & $6.40 \times 10^{-5}$ \\
\hline & Sumoylation Pathway\& & $5.57 \times 10^{-4}$ \\
\hline & $\begin{array}{c}\text { Urate Biosynthesis/Inosine } 5^{\prime} \text {-phosphate } \\
\text { Degradation * }\end{array}$ & $1.00 \times 10^{-3}$ \\
\hline & eIF2 Signaling & $1.39 \times 10^{-3}$ \\
\hline
\end{tabular}

Among the canonical pathways regulated by oxidants several signaling pathways, including Ran (Ras-related nuclear protein), TOR, Rho, and eIF2 (eukaryotic initiation factor 2) signaling, were previously implicated in stress response, but their precise role in different oxidant recognition and downstream signal transduction remained elusive [22-24]. We observed however that Ran signaling pathway significantly enriched in all treatments to a different degree, suggesting a different mode of action (Figure 3). Ran GTPase is a guanosine triphosphate (GTP) binding protein involved in nucleocytoplasmic transport [25]. The S. cerevisiae homologue of the Ran GTPase is Gsp1p [25]. Two nucleotide forms of Ran (RanGTP and RanGDP) generate a gradient between the nucleus and cytoplasm [26]. The nucleocytoplasmic transport controls signal transduction, gene expression, cell-cycle progression, apoptosis, and regulation of stress response [27]. It also regulates ubiquitin-mediated protein degradation during the cell cycle [28]. Ran GTPase requires localization to the nucleus and GTP loading by the chromatin-associated exchange factor RCC1, a protein that promotes the exchange of Ran-bound guanosine diphosphate (GDP) by GTP [29]. Despite Ran signaling not been extensively studied in response to different oxidants, several studies outlined its role in response to $\mathrm{H}_{2} \mathrm{O}_{2}$ [22]. $\mathrm{H}_{2} \mathrm{O}_{2}$-induced oxidative stress has shown to collapse the nucleocytoplasmic Ran GTPase gradient in growing 
cells, leading to inhibition of the nuclear import [30]. Sensitivity to oxidative stress causes redistribution of the small GTPase Gsp1p/Ran from the nucleus to the cytoplasm, causing nuclear import inhibition [31]. This leads to elevation of cytoplasmic GTPase levels. Small GTPase, Gsp1p/Ran, also plays a major role in nuclear localization of Yap1p (AP-1-like transcription factor), which is a transcription factor essential for oxidative stress response in yeast [32]. Our results also show upregulation of the SRM1 (nucleotide exchange factor for Gsp1p) by diamide and $\mathrm{H}_{2} \mathrm{O}_{2}$ and downregulation by menadione and $\mathrm{CHP}$.

It has been previously shown that oxidative stress causes oxidation of cysteine residues in RCC1, which can disrupt the Ran signaling [22]. Cysteine oxidation is a well-established biomarker of oxidative stress. Oxidation of cysteine residues can change the function of a protein in networks of kinases, phosphatases and apoptotic cascades, and can cause changes in transcriptional activity [33]. Hence, additional studies on posttranslational modifications, including oxidative posttranslational modifications, are required to further understand the role of Ran signaling in early response to different oxidants.

TOR signaling in S. cerevisiae is involved in cell growth, ribosome biogenesis, translation initiation, metabolism, stress response, aging, and autophagy [34]. TOR is a Ser/Thr-protein kinase that is evolutionary conserved [35]. The cells lacking TORC1 have shown sensitivity to oxidative stress, suggesting TOR signaling plays an important role in stress response [23]. The other important role of TOR signaling is the transcriptional regulation of MSN2/4, an important transcription factor in response to oxidative stress [23]. We observed significant regulation of TOR signaling in all four oxidant treatments (Supplementary Figure S1).

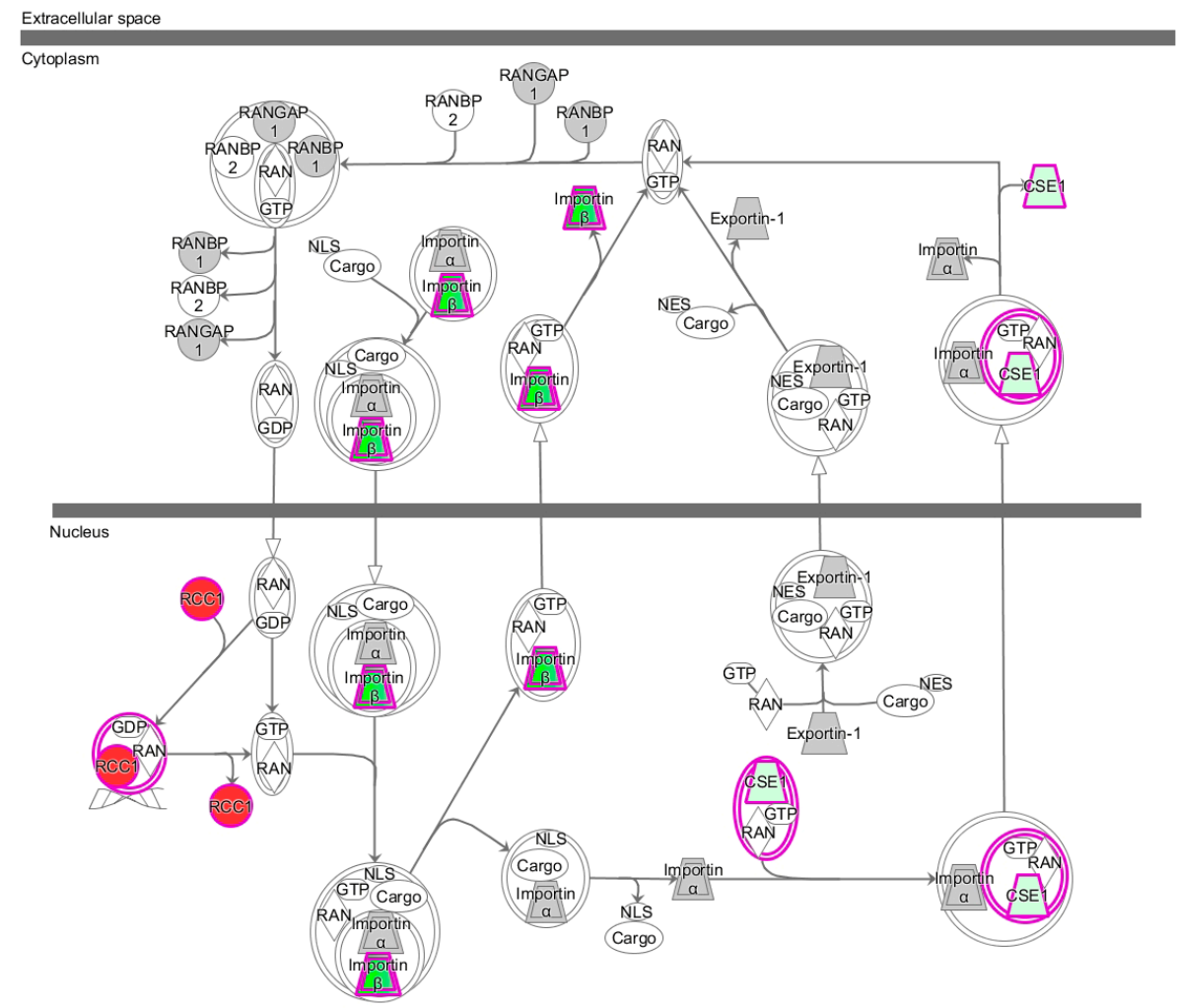

(A)

Figure 3. Cont. 


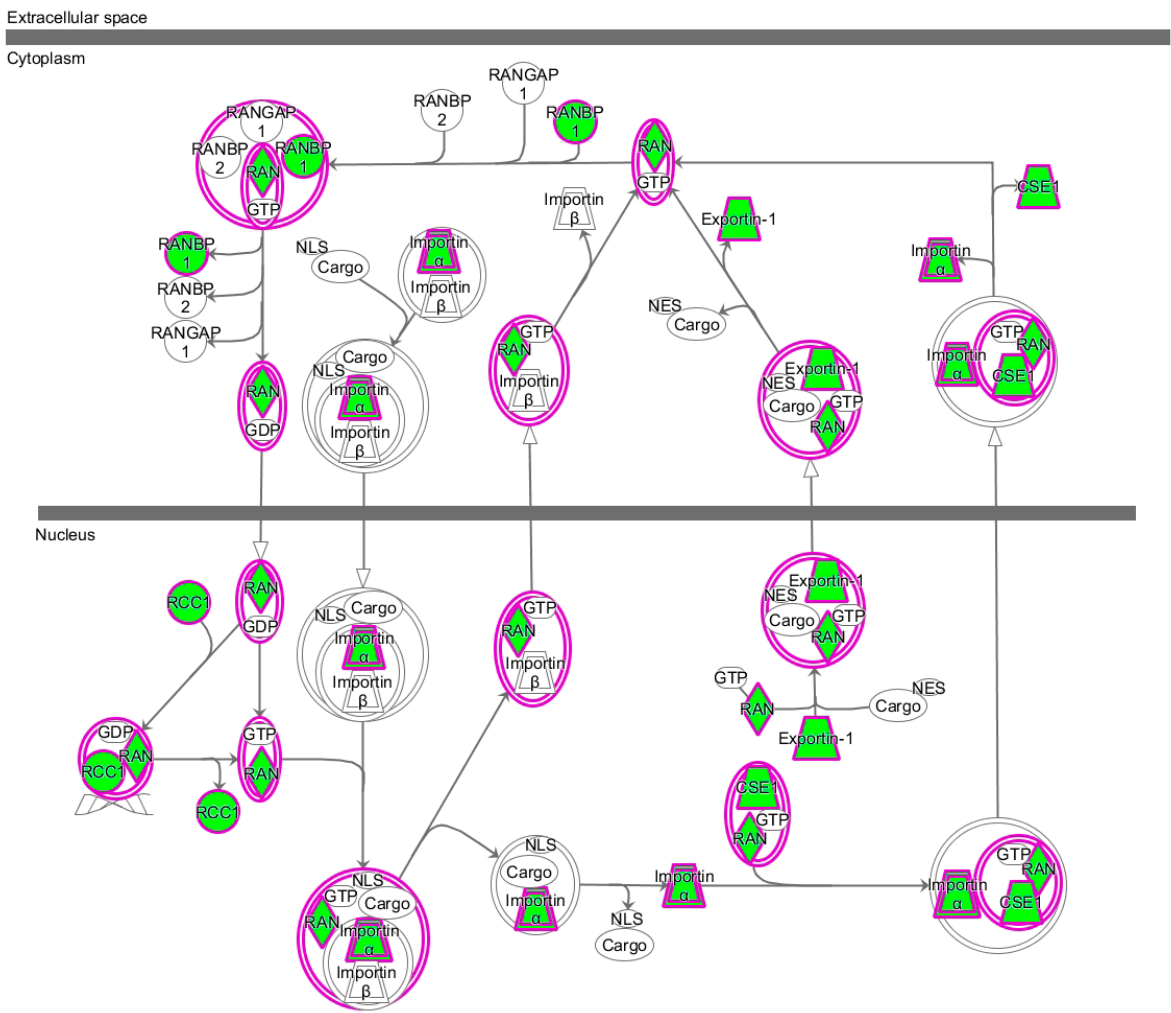

(B)



(C)

Figure 3. Cont. 


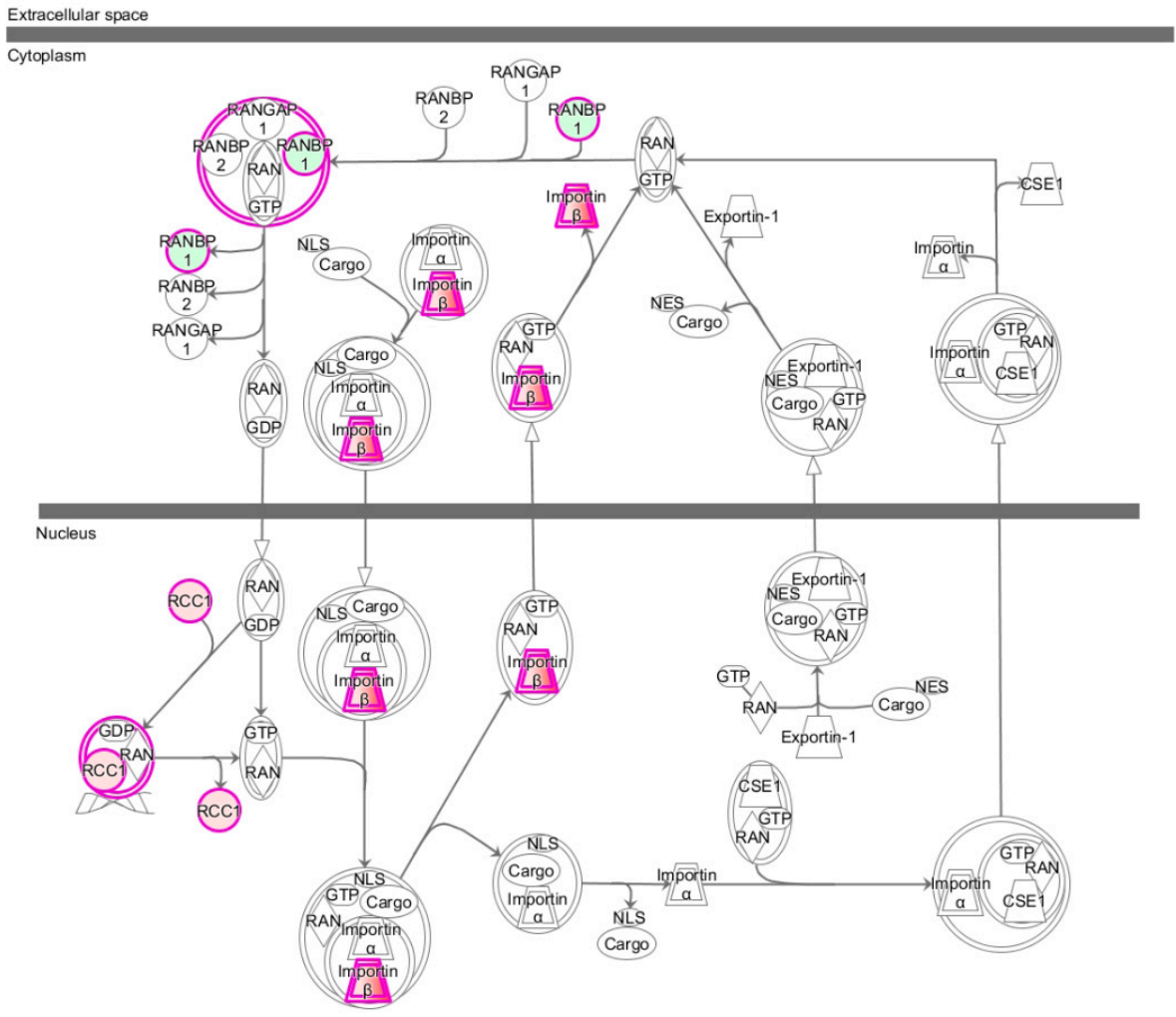

(D)

Figure 3. Regulation of the canonical Ran signaling pathway in S. cerevisiae response to oxidants at 3 min by (A) $\mathrm{H}_{2} \mathrm{O}_{2}$ and (B) CHP. Regulation of the canonical Ran signaling pathway in S. cerevisiae response to oxidants at $3 \mathrm{~min}$ by (C) menadione and (D) diamide. Networks were constructed using IPA ${ }^{\circledR}$ based on global untargeted proteomics analysis using label-free quantification relying on precursor ions of tryptic peptides based on high-resolution (Orbitrap) mass spectrometry. Regulation of the pathways and individual components are indicated by color: green for protein downregulation, red for protein upregulation, blue for pathway inhibition, and orange for pathway activation.

We found that a significant response of TOR signaling was associated with downregulation of several protein components of the small (40S) ribosomal subunits. The largest number of downregulated components of the small (40S) ribosomal subunits was observed in CHP treatment. Our result is consistent with the established role of TOR signaling in ribosome biogenesis [34]. Regulation of TOR signaling by ROS could contribute to alteration of cell viability, cell cycle progression and translation initiation.

\subsection{MAPK Cascade Module and Signal Transduction}

Cells acquire various signal transduction pathways to transmit external molecular signals effectively into the cell [36]. Eukaryotic cells have a conserved module composed of three protein kinases; the mitogen-activated protein kinase (MAPK) cascade to transduce the extremal stimuli [37]. The three kinases are: MAPK (also known as extracellular signal-regulated kinase (ERK)), MAPK kinase (MAPKK, also known as mitogen-activated, ERK-activating kinase (MEK)), and MAPK kinase kinase (MAPKKK, also known as MEK kinase (MEKK)) [37]. Many components of the MAPK module and their functions found in S. cerevisiae are conserved in eukaryotes [38]. MAPK cascades regulate many physiological processes such as the life cycle of budding and fission yeasts, pheromone response pathway for conjugation and meiosis, high-osmolarity sensing pathway for osmotic stress, hypoosmolarity and heat-sensing pathway for cell wall biosynthesis [36]. MAPK cascades also activate a subset of the components of the pheromone response pathway for pseudohyphal growth [36]. 
During oxidative stress, Rho1 GTPase regulates cell wall integrity (CWI) by activating the MAPK cascade for CWI signaling. This is the main route responsible for maintaining homeostasis in the cell wall [39]. Guanosine dissociation inhibitor (GDI) proteins play a major role in controlling both the timing and the localization of Rho1 GTPase activity. Cell surface sensors such as Wsc1, Mlt1 and Mid2 interact with Rom2 and activate Rho1 as a stress response [24]. This activates yeast protein kinase C (Pkc1) and Pkc1 phosphorylates MAPKKK Bck1 trigger the MAPK module. This phosphorylation stimulates Mkk1 and Mkk2, which phosphorylate and activate Slt2/Mpk1. Cyclin dependent protein kinase (CDK) at the G1-S transition [40] and polo kinase are also responsible in activating Rho1 [41]. Rho1 activity is dependent on TORC1 signaling [42] TORC2 signaling [43], and phospholipid metabolism [44]. It has also been found that oxidative stress may prevent activation of pheromone signaling and high-osmolarity glycerol response (HOG) pathways, suggesting crosstalk mechanisms between them [45].

Interestingly, we observed Rho signaling significantly altered in all the treatments. However, their regulation differed amongst the treatments. In $\mathrm{H}_{2} \mathrm{O}_{2}$-treated cells, there was a downregulation of Rho GDP-dissociation inhibitor, suggesting disruption of the GDP/GTP exchange reaction of the Rho proteins by facilitating the dissociation of GDP from them, and the obstructing of subsequent binding of GTP. Furthermore, depletion of the Rho GDP-dissociation inhibitor results in degradation of Rho1 and cell division cycle protein 42 (Cdc42) by the proteasome [46]. In menadione-treated cells, there was downregulation of GTP-binding protein Rho3. This phenomenon is also linked to slow growth (Figure S2), as Rho3 are known to regulate polarized secretion and the actin cytoskeleton [47]. In CHP-treated cells, we observed downregulation of the GTP-binding protein Rho3, GTP-binding protein Rho1 and Rho GDP-dissociation inhibitor, also suggesting disruption of Rho protein signal transduction. In diamide-treated cells, there was upregulation of Rho1 GDP-GTP exchange protein 2 and Rho GDP-dissociation inhibitor, suggesting induced Rho signaling in response to diamide. Our result indicated that $\mathrm{H}_{2} \mathrm{O}_{2}$, menadione and CHP compromised the overall cell wall integrity; however, diamide stimulated downstream signaling pathway (Figure 4). As mentioned above, there are crosstalks between these pathways. Oxidative stress was shown to disrupt recruitment of (Ste5) and its associated proteins to the plasma membrane and reduce nuclear translocation of the MAPK protein Hog1, causing inhibition of pheromone signaling pathways and the HOG pathway, respectively [45]. We observed that Hog1 was downregulated in all four treatments, which infers the interference in the HOG pathway.

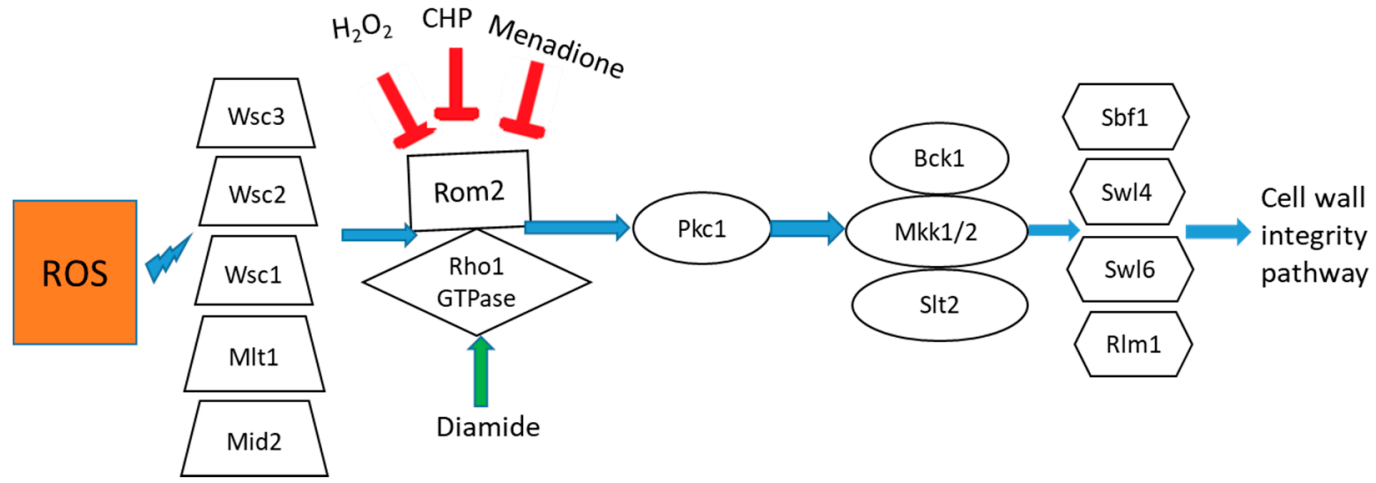

Figure 4. Model for how different oxidants affect the Rho protein signal transduction in S. cerevisiae at 3 min. Menadione, $\mathrm{CHP}$ and $\mathrm{H}_{2} \mathrm{O}_{2}$-induced oxidative stress disrupt the signal transduction, causing defective cell wall homeostasis. Symbols: protein kinases, ovals; guanosine triphosphate (GTP)-binding proteins, diamonds; scaffold, adaptor, and activating proteins, rectangles; cell surface proteins, trapezoids; transcription factors, hexagon; activation, arrows; inhibition, T-bars.

Although there is a vast body of research on oxidative stress in biological systems and the role it plays in various diseases, several aspects of the oxidative stress response remain elusive [1-4,7-14,48-52]. Very little is known about early signaling events in stress 
response that trigger specific defensive mechanisms to a given oxidant, which can make the difference between survival and death. It has been proposed that early transcriptional events, changes in protein expression and patterns of posttranslational modifications, along with rapid changes in the metabolome, coordinate complex molecular networks controlling rapid reprogramming of cellular metabolism and activation of defense pathways [53-58]. A detailed understanding of these processes is required to design new approaches for combating stress-induced pathologies.

Current understanding of oxidative stress responses in yeast has mostly derived from studies focused on later time points. It was shown that gene expression in stress response as early as $30 \mathrm{~s}$ [46]; therefore, it is essential to investigate early responses to oxidative stress. The early signaling mechanism(s) that control oxidant perception and signal transduction leading to activation of the antioxidant defense response and survival mechanisms tailored toward specific oxidative insult is crucial for comprehensive understanding of oxidative stress and biochemical and signaling networks mediating stress response. Our results using label-free proteomics relying on precursor ions tryptic peptides quantified by high-resolution (Orbitrap) mass spectrometry have shown that specific proteome-level response is triggered, indeed, to different oxidants within minutes after treatment and several signaling networks are activated and may be responsible for furnishing oxidant specific defenses.

\section{Materials and Methods}

\subsection{Yeast Strains and Culture Media}

Yeast strain BY4743 ([4741/4742] MATa/MAT $\alpha$ his3delta1/his3delta1 leu2delta0/ leu2delta0 lys2delta0/+met15delta0/+ura3delta0/ura3-delta0) was obtained from American Type Culture Collection (ATCC, Manassas, VA, USA, Catalog\#201390). Cultures were kept in long-term storage frozen at $-80^{\circ} \mathrm{C}$ in glycerol stocks. Work cultures were kept at $4{ }^{\circ} \mathrm{C}$ in Yeast Extract-Peptone-Dextrose (YPD) Medium (yeast extract $0.1 \%(w / v)$, peptone $0.5 \%(w / v)$ and dextrose $2 \%(w / v))$ agar plates.

\subsection{Cell Growth and Oxidative Stress Conditions}

S. cerevisiae cells were initially batch grown overnight at $30^{\circ} \mathrm{C}, \mathrm{pH} 6.0,150 \mathrm{rpm}$, in minimal medium $(25 \mathrm{~mL})$ containing Difco yeast nitrogen base without amino acids, $2 \%(w / v)$ dextrose supplemented with uracil $20 \mathrm{mg} / \mathrm{L}$, L-leucine $60 \mathrm{mg} / \mathrm{L}$ and L-histidine $20 \mathrm{mg} / 1$ until mid-exponential phase was reached, based on measuring optical density measurement at $600 \mathrm{~nm}\left(\mathrm{OD}_{600} \sim 1.5\right)$. The inoculum from overnight culture was used to inoculate minimal media $(25 \mathrm{~mL})$ containing Difco yeast nitrogen base without amino acids, $2 \%(w / v)$ dextrose supplemented with uracil $20 \mathrm{mg} / \mathrm{L}$, L-leucine $60 \mathrm{mg} / \mathrm{L}$ and L-histidine $20 \mathrm{mg} / \mathrm{L}$. The cultures were grown at $30^{\circ} \mathrm{C}, \mathrm{pH} 6.0,150 \mathrm{rpm}$. Conditions of oxidative stress were achieved by the addition of $1.2 \mathrm{mM} \mathrm{H}_{2} \mathrm{O}_{2}, \mathrm{CHP} 190 \mu \mathrm{M}$, menadione $150 \mu \mathrm{M}$, and diamide $1.5 \mathrm{mM}$ at the mid-exponential phase $\left(\mathrm{OD}_{600} \sim 1.5\right)$. Controls without $\mathrm{CHP}$ were made by adding the same volume of $95 \%(v / v)$ ethanol (the solvent for $\mathrm{CHP}$ ). Controls without menadione were made by adding the same volume of $100 \%(v / v)$ DMSO (the solvent for menadione). Controls without $\mathrm{H}_{2} \mathrm{O}_{2}$ and diamide were not treated with any chemical, as their solvent is water. Three biological replicates were carried out for each condition.

\subsection{Sample Collection and Processing}

Samples were collected at $3 \mathrm{~min}$ after the addition of oxidants. To quench metabolism, cells were harvested in aqueous $40 \%$ ethanol $(v / v)$ solution containing $0.8 \% \mathrm{NaCl}(w / v)$, kept at $-40{ }^{\circ} \mathrm{C}$ using a dry ice-ethanol bath, as described in Spura et al. [59]. Samples were centrifuged for $5 \mathrm{~min}$ at $1000 \times g$ and $-10^{\circ} \mathrm{C}$. Temperature was monitored after centrifugation to ensure that it was below $-35^{\circ} \mathrm{C}$. The supernatants were discarded and the pellets were suspended in 100\% methanol, freeze-dried for $48 \mathrm{~h}$ using a Labconco 79480 Freeze Dry System (Labconco, Kansas City, MO, USA) and stored at $-80^{\circ} \mathrm{C}$ until use. 


\subsection{Protein Extraction and Digestion}

Proteins were extracted using a lysis buffer made of $8 \mathrm{M}$ urea in $25 \mathrm{mM}$ ammonium bicarbonate One $\mathrm{mL}$ of lysis buffer was added to $35 \mathrm{mg}$ (dry weight) of yeast cells and vortexed for a $1 \mathrm{~min}$ to ensure proper resuspension. Two hundred $\mu \mathrm{L}$ of $0.5 \mathrm{~mm}$ glass beads were added. The pellet was milled for $2 \mathrm{~min}$ at $30 \mathrm{~Hz}$ in the Retsch Mixer Mill MM 300 (Retsch $\mathrm{GmbH}$, Haan, Germany) and kept in ice for $1 \mathrm{~min}$. This step was repeated 5 times. Samples were centrifuged for $15 \mathrm{~min}$ at $20,000 \times \mathrm{g}$ at $4{ }^{\circ} \mathrm{C}$ in a refrigerated microcentrifuge and the supernatant was transferred into a clean tube. Protein concentration was determined using Nanodrop 2000 (Thermo Fisher Scientific, Waltham, MA, USA) after calculating the appropriate volume containing $100 \mu \mathrm{g}$ of protein, $25 \mathrm{mM}$ of $\mathrm{ABC}$ was added to bring the volume to $100 \mu \mathrm{L}$. The extracted proteins were reduced with dithiothreitol and incubated at $56^{\circ} \mathrm{C}$ for $30 \mathrm{~min}$ and carbamidomethylated by addition of $200 \mathrm{mM}$ iodoacetamide $[16,60]$. The samples were then diluted 9-fold with $25 \mathrm{mM}$ ammonium bicarbonate and digested overnight at $37^{\circ} \mathrm{C}$ with trypsin. The enzymatic digestion was then stopped by acidifying the sample with $15 \mu \mathrm{L}$ of acetic acid.

\subsection{Solid Phase Extraction (SPE)}

The digested protein was cleaned up using a SOLA HRP cartridge (Thermo Scientific, Runcorn, Cheshire, UK). After activating and equilibrating the column bed with $500 \mu \mathrm{L}$ of acetonitrile, the bed was equilibrated with $2 \times 500 \mu \mathrm{L}$ of $0.1 \%$ TFA in water. The protein was eluted in 10 fractions using the elution solvents $(2 \times 250 \mu \mathrm{L})$ in the Supplementary Table S1. Fractions were dried in a vacuum concentrator and re-suspended in $150 \mu \mathrm{L}$ of $5 \%$ acetonitrile and $0.1 \%$ formic acid $(v / v)$ in water for LC-MS/MS analysis.

\subsection{Data-Dependent NanoLC-MS/MS Analyses}

The digested peptides were analyzed employing a hybrid linear ion trap (LTQ) Orbitrap Velos Pro mass spectrometer (Thermo Scientific, San Jose, CA, USA) equipped with a Proxeon (Odense, Denmark) nanoelectrospray ionization (NSI) source and connected to a nanoACQUITY UPLC System (Waters Corporation, Milford, MA, USA). A nanoEaseTM M/Z HSS T3 analytical column, $75 \mathrm{~mm} \times 150 \mathrm{~cm}$ (Waters Corporation, Milford, MA; $\mathrm{PN}$ : 186008816) was used for peptide separation at $400 \mathrm{~nL} / \mathrm{min}$ flow rate using 3-h linear gradient (from $5 \%$ to $95 \%$ B). The eluent system consisted of (A) $0.1 \%$ formic acid in water $(v / v)$ and (B) $0.1 \%$ formic acid in acetonitrile $(v / v)$. Peptides were eluted through a Picotip emitter (internal diameter $10 \pm 1 \mu \mathrm{m}$; New Objective, Woburn, MA, USA) and directly sampled by the nano-electrospray source of the mass spectrometer in a positive ion mode. NSI spray voltage and capillary temperature maintained during the gradient run were $1.8 \mathrm{kV}$ and $250{ }^{\circ} \mathrm{C}$ respectively.

FT full-scan mass spectra were attained at 60,000 mass resolving power $(\mathrm{m} / \mathrm{z} 400)$ in the $\mathrm{m} / \mathrm{z}$ range of 350 to 1650 . Collision induced dissociation (CID) was achieved using helium in the linear ion trap to obtain MS/MS product ion scans of the top ten most abundant precursor ions from the full scan mass spectra using a 2.5 Da isolation width and normalized collision energy of $35 \%$. The precursor ions selected for CID were then dynamically excluded from further MS/MS analysis for $30 \mathrm{~s}$.

\subsection{Data Processing and Statistical Analysis}

MS and MS/MS data were analyzed using the SEQUEST HT algorithm in the Proteome Discoverer (version 2.4, Thermo Fisher Scientific, San Jose, CA, USA. Protein identification and quantification were conducted against the FASTA database composed of $S$. cerevisiae Uniprot protein database (6049 entries). SEQUEST search parameters included: peptide length $>5$ amino acids, maximum of one tryptic missed cleavage events, cysteine carbamidomethylation as a fixed modification and oxidation of methionine and deamidation of glutamine and asparagine as variable modifications, precursor mass tolerance of $25 \mathrm{ppm}$ and fragment mass tolerance of $0.80 \mathrm{Da}$. Peptide false discovery rate (FDR) was directly determined by the target-decoy strategy. PSMs and protein level FDR were both set at $1 \%$. 
Total ion current (TIC) normalization signal to noise ratio was set to 2 . Fold changes of the proteins were calculated from normalized precursor intensity values by comparing the treatment conditions to control. Student's $t$-tests were used to determine statistically significant differential protein expressions $(p<0.05)$, and the fold change threshold was set to \pm 2.0 . We uploaded our data to the ProteomeXchange Consortium [61] by the PRIDE partner repository (assigned dataset identifier: PXD022685).

\subsection{Bioinformatics}

Differentially expressed proteins from each oxidant group were submitted with UniProt identifiers and fold changes to Ingenuity Pathway Analysis ${ }^{\circledR}\left(\right.$ IPA $^{\circledR}$, QIAGEN, Redwood City, CA, USA) for core analysis. The matched proteins were used to generate molecular networks including canonical pathways and upstream regulatory analysis. The core analysis allowed us to delineate specific response to different oxidants. IPA ${ }^{\circledR}$ also predicted possible upstream regulators of the proteins in this study, which were assigned as inhibited or activated according to the Z-score, a statistical result of differential protein expression according to the fold changes. IPA ${ }^{\circledR}$ employs right-tailed Fisher's exact test to calculate the overlaps of $p$-values [62].

\section{Conclusions}

In summary, our comparative proteomics analysis has revealed unique early signaling response of Saccharomyces cerevisiae to oxidants with different mechanism of action as early as $3 \mathrm{~min}$ after treatment. Our goal was to identify early signaling mechanisms involved in oxidant recognition and molecular switches that trigger differential response to oxidants with different mechanism of action.

We performed global untargeted proteomics to map out the proteome under oxidative stress generated by four distinct oxidative stress-inducing chemicals, namely $\mathrm{H}_{2} \mathrm{O}_{2}$, menadione, CHP, and diamide. We found that different oxidants elicit diverse proteomic responses, suggesting activation of different signal transduction pathways by each oxidant. According to our pathway analyses, these proteins participated in 25 different networks, and signaling pathways mostly regulated by oxidants at early time points were Ran, TOR, Rho, and eIF2. Furthermore, each oxidant regulated these pathways in a unique way indicating specificity in the response to different oxidants having different modes of action. Interplay of signaling pathway may be important in recognizing different oxidants and may trigger different downstream MAPK signaling cascades and induce specific response to each oxidant. Therefore, it is imperative to use a combination of genetic analysis and omics studies to identify the specific role of each pathway and individual signaling components regulated by different oxidants. Many identified proteins are subject to posttranslational regulation by phosphorylation and oxidative modification; therefore, more studies on the role of specific posttranslational modifications in early oxidative stress response signaling are required to further understand the specific signaling mechanism triggered by each oxidant. It is also important to study the differential dynamics of protein networks perturbed by each oxidant to identify downstream signaling events and to determine if any of these early responses are transient or have long-term impact on cellular functions.

Supplementary Materials: Supplementary materials can be found at https://www.mdpi.com/1422 $-0067 / 22 / 1 / 167 /$ s1. Table S1: Elution solvents for high-pH reversed-phase fractionation of protein digests, Table S2: Lists of identified and validated proteins using Proteome Discoverer 2.4, along with their gene ontology (GO) annotations, Table S3: Lists of regulated S. cerevisiae proteins, Table S4: Top five protein networks generated by IPA ${ }^{\circledR}$ using significantly regulated proteins identified by label-free quantitative proteomics performed in $S$. cerevisiae strains treated with the four different oxidants, Figure S1: TOR signaling in S. cerevisiae in response to different oxidants at 3 min, Figure S2: Growth curve analysis of S. cerevisiae under increasing oxidative stress.

Author Contributions: Conceptualization, V.S. and L.P.; methodology, V.S., L.P., P.P. and K.Z.; investigation, P.P. and K.Z.; resources, V.S. and L.P.; data curation, K.Z.; writing-original draft 
preparation, P.P. and V.S.; writing-review and editing, L.P. and K.Z.; visualization, P.P. and K.Z.; supervision, V.S. and L.P.; project administration, V.S. and L.P.; funding acquisition, V.S. and L.P. All authors have read and agreed to the published version of the manuscript.

Funding: This research was funded by an AERI Seed Grant (V.S.) and by The Welch Foundation (endowment BK-0031, L.P.).

Institutional Review Board Statement: Not applicable.

Informed Consent Statement: Not applicable.

Data Availability Statement: Raw data were made available through the ProteomeXchange Consortium [61] by the PRIDE partner repository (assigned dataset identifier: PXD022685).

Conflicts of Interest: The authors declare no conflict of interest.

\section{References}

1. Nita, M.; Grzybowski, A. The role of the reactive oxygen species and oxidative stress in the pathomechanism of the age-related ocular diseases and other pathologies of the anterior and posterior eye segments in adults. Oxid. Med. Cell Longev. 2016, 2016, 3164734. [CrossRef] [PubMed]

2. Deavall, D.G.; Martin, E.A.; Horner, J.M.; Roberts, R. Drug-induced oxidative stress and toxicity. J. Toxicol. 2012, $2012,645460$. [CrossRef] [PubMed]

3. Bae, Y.S.; Oh, H.; Rhee, S.G.; Yoo, Y.D. Regulation of reactive oxygen species generation in cell signaling. Mol. Cells 2011, 32, 491-509. [CrossRef] [PubMed]

4. Larosa, V.; Remacle, C. Insights into the respiratory chain and oxidative stress. Biosci. Rep. 2018, 38. [CrossRef]

5. Fleury, C.; Mignotte, B.; Vayssiere, J.L. Mitochondrial reactive oxygen species in cell death signaling. Biochimie 2002, 84, 131-141.

6. Ortuno-Sahagun, D.; Pallas, M.; Rojas-Mayorquin, A.E. Oxidative stress in aging: Advances in proteomic approaches. Oxid. Med. Cell Longev. 2014, 2014, 573208. [CrossRef]

7. Droge, W. Free radicals in the physiological control of cell function. Physiol Rev. 2002, 82, 47-95.

8. Yakes, F.M.; Van Houten, B. Mitochondrial DNA damage is more extensive and persists longer than nuclear DNA damage in human cells following oxidative stress. Proc. Natl. Acad. Sci. USA 1997, 94, 514-519. [CrossRef]

9. Bilinski, T.; Litwinska, J.; Blaszczynski, M.; Bajus, A. Superoxide dismutase deficiency and the toxicity of the products of autooxidation of polyunsaturated fatty acids in yeast. Biochim. Biophys. Acta 1989, 1001, 102-106. [CrossRef]

10. Cabiscol, E.; Piulats, E.; Echave, P.; Herrero, E.; Ros, J. Oxidative stress promotes specific protein damage in Saccharomyces cerevisiae. J. Biol. Chem. 2000, 275, 27393-27398.

11. Moradas-Ferreira, P.; Costa, V. Adaptive response of the yeast Saccharomyces cerevisiae to reactive oxygen species: Defences, damage and death. Redox. Rep. 2000, 5, 277-285. [PubMed]

12. Demasi, A.P.; Pereira, G.A.; Netto, L.E. Yeast oxidative stress response. Influences of cytosolic thioredoxin peroxidase I and of the mitochondrial functional state. FEBS J. 2006, 273, 805-816. [CrossRef] [PubMed]

13. Botstein, D.; Chervitz, S.A.; Cherry, J.M. Yeast as a model organism. Science 1997, 277, 1259-1260. [CrossRef] [PubMed]

14. Thorpe, G.W.; Fong, C.S.; Alic, N.; Higgins, V.J.; Dawes, I.W. Cells have distinct mechanisms to maintain protection against different reactive oxygen species: Oxidative-stress-response genes. Proc. Natl. Acad. Sci. USA 2004, 101, 6564-6569.

15. Sha, W.; Martins, A.M.; Laubenbacher, R.; Mendes, P.; Shulaev, V. The genome-wide early temporal response of Saccharomyces cerevisiae to oxidative stress induced by cumene hydroperoxide. PLoS ONE 2013, 8, e74939. [CrossRef]

16. Prokai-Tatrai, K.; Xin, H.; Nguyen, V.; Szarka, S.; Blazics, B.; Prokai, L.; Koulen, P. 17 $\beta$-Estradiol eye drops protect the retinal ganglion cell layer and preserve visual function in an in vivo model of glaucoma. Mol. Pharm. 2013, 10, 3253-3261. [CrossRef]

17. Frye, M.; Blanco, S. Post-transcriptional modifications in development and stem cells. Development 2016, 143, 3871-3881. [CrossRef]

18. Patterson, J.C.; Joughin, B.A.; van de Kooij, B.; Lim, D.C.; Lauffenburger, D.A.; Yaffe, M.B. ROS and oxidative stress are elevated in mitosis during asynchronous cell cycle progression and are exacerbated by mitotic arrest. Cell Syst. 2019, 8, 163-167.e2. [CrossRef]

19. Santos, A.L.; Lindner, A.B. Protein posttranslational modifications: Roles in aging and age-related disease. Oxid. Med. Cell Longev. 2017, 2017, 5716409. [CrossRef]

20. Simon, H.U.; Haj-Yehia, A.; Levi-Schaffer, F. Role of reactive oxygen species (ROS) in apoptosis induction. Apoptosis 2000, 5, 415-418. [CrossRef]

21. Toth, A.; Aufschnaiter, A.; Fedotovskaya, O.; Dawitz, H.; Adelroth, P.; Buttner, S.; Ott, M. Membrane-tethering of cytochrome c accelerates regulated cell death in yeast. Cell Death Dis. 2020, 11, 722. [CrossRef] [PubMed]

22. Chatterjee, M.; Paschal, B.M. Disruption of the Ran system by cysteine oxidation of the nucleotide exchange factor RCC1. Mol. Cell Biol. 2015, 35, 566-581. [CrossRef]

23. Crespo, J.L.; Hall, M.N. Elucidating TOR signaling and rapamycin action: Lessons from Saccharomyces cerevisiae. Microbiol. Mol. Biol. Rev. 2002, 66, 579-591. [CrossRef] [PubMed]

24. Levin, D.E. Cell wall integrity signaling in Saccharomyces cerevisiae. Microbiol. Mol. Biol. Rev. 2005, 69, 262-291. [CrossRef] 
25. Oki, M.; Nishimoto, T. A protein required for nuclear-protein import, Mog1p, directly interacts with GTP-Gsp1p, the Saccharomyces cerevisiae ran homologue. Proc. Natl. Acad. Sci. USA 1998, 95, 15388-15393. [CrossRef] [PubMed]

26. Cavazza, T.; Vernos, I. The RanGTP Pathway: From Nucleo-cytoplasmic transport to spindle assembly and beyond. Front. Cell Dev. Biol. 2015, 3, 82. [CrossRef] [PubMed]

27. Kodiha, M.; Stochaj, U. Nuclear transport: A switch for the oxidative stress-signaling circuit? J. Signal. Transduct. 2012, 2012, 208650. [CrossRef]

28. Matunis, M.J.; Coutavas, E.; Blobel, G. A novel ubiquitin-like modification modulates the partitioning of the Ran-GTPaseactivating protein RanGAP1 between the cytosol and the nuclear pore complex. J. Cell Biol. 1996, 135, 1457-1470. [CrossRef]

29. Moore, J.D. The Ran-GTPase and cell-cycle control. Bioessays 2001, 23, 77-85. [CrossRef]

30. Czubryt, M.P.; Austria, J.A.; Pierce, G.N. Hydrogen peroxide inhibition of nuclear protein import is mediated by the mitogenactivated protein kinase, ERK2. J. Cell Biol. 2000, 148, 7-16. [CrossRef]

31. Kodiha, M.; Chu, A.; Matusiewicz, N.; Stochaj, U. Multiple mechanisms promote the inhibition of classical nuclear import upon exposure to severe oxidative stress. Cell Death Differ. 2004, 11, 862-874. [CrossRef] [PubMed]

32. Isoyama, T.; Murayama, A.; Nomoto, A.; Kuge, S. Nuclear import of the yeast AP-1-like transcription factor Yap1p is mediated by transport receptor Pse1p, and this import step is not affected by oxidative stress. J. Biol. Chem. 2001, 276, 21863-21869. [CrossRef] [PubMed]

33. Frijhoff, J.; Winyard, P.G.; Zarkovic, N.; Davies, S.S.; Stocker, R.; Cheng, D.; Knight, A.R.; Taylor, E.L.; Oettrich, J.; Ruskovska, T.; et al. Clinical relevance of biomarkers of oxidative stress. Antioxid. Redox. Signal. 2015, 23, 1144-1170. [CrossRef] [PubMed]

34. Schmelzle, T.; Hall, M.N. TOR, a central controller of cell growth. Cell 2000, 103, 253-262. [CrossRef]

35. Gonzalez, A.; Hall, M.N. Nutrient sensing and TOR signaling in yeast and mammals. EMBO J. 2017, 36, 397-408. [CrossRef] [PubMed]

36. Banuett, F. Signalling in the yeasts: An informational cascade with links to the filamentous fungi. Microbiol. Mol. Biol. Rev. 1998, 62, 249-274. [CrossRef]

37. Robinson, M.J.; Cobb, M.H. Mitogen-activated protein kinase pathways. Curr. Opin. Cell Biol. 1997, 9, 180-186. [CrossRef]

38. Chen, R.E.; Thorner, J. Function and regulation in MAPK signaling pathways: Lessons learned from the yeast Saccharomyces cerevisiae. Biochim. Biophys. Acta 2007, 1773, 1311-1340. [CrossRef]

39. Levin, D.E. Regulation of cell wall biogenesis in Saccharomyces cerevisiae: The cell wall integrity signaling pathway. Genetics 2011, 189, 1145-1175. [CrossRef]

40. Kono, K.; Nogami, S.; Abe, M.; Nishizawa, M.; Morishita, S.; Pellman, D.; Ohya, Y. G1/S cyclin-dependent kinase regulates small GTPase Rho1p through phosphorylation of RhoGEF Tus1p in Saccharomyces cerevisiae. Mol. Biol. Cell 2008, 19, $1763-1771$. [CrossRef]

41. Yoshida, S.; Kono, K.; Lowery, D.M.; Bartolini, S.; Yaffe, M.B.; Ohya, Y.; Pellman, D. Polo-like kinase Cdc5 controls the local activation of Rho1 to promote cytokinesis. Science 2006, 313, 108-111. [CrossRef] [PubMed]

42. Petkova, M.I.; Pujol-Carrion, N.; Arroyo, J.; Garcia-Cantalejo, J.; Angeles de la Torre-Ruiz, M. Mtl1 is required to activate general stress response through Tor1 and Ras2 inhibition under conditions of glucose starvation and oxidative stress. J. Biol. Chem. 2010, 285, 19521-19531. [CrossRef] [PubMed]

43. Ho, H.L.; Lee, H.Y.; Liao, H.C.; Chen, M.Y. Involvement of Saccharomyces cerevisiae Avo3p/Tsc11p in maintaining TOR complex 2 integrity and coupling to downstream signaling. Eukaryotic Cell 2008, 7, 1328-1343. [CrossRef] [PubMed]

44. Audhya, A.; Emr, S.D. Stt4 PI 4-kinase localizes to the plasma membrane and functions in the Pkc1-mediated MAP kinase cascade. Dev. Cell 2002, 2, 593-605. [CrossRef]

45. Lee, B.; Jeong, S.G.; Jin, S.H.; Mishra, R.; Peter, M.; Lee, C.S.; Lee, S.S. Quantitative analysis of yeast MAPK signaling networks and crosstalk using a microfluidic device. Lab Chip 2020, 20, 2646-2655. [CrossRef]

46. Boulter, E.; Garcia-Mata, R.; Guilluy, C.; Dubash, A.; Rossi, G.; Brennwald, P.J.; Burridge, K. Regulation of Rho GTPase crosstalk, degradation and activity by RhoGDI1. Nat. Cell Biol. 2010, 12, 477-483. [CrossRef]

47. Robinson, N.G.; Guo, L.; Imai, J.; Toh, E.A.; Matsui, Y.; Tamanoi, F. Rho3 of Saccharomyces cerevisiae, which regulates the actin cytoskeleton and exocytosis, is a GTPase which interacts with Myo2 and Exo70. Mol. Cell Biol. 1999, 19, 3580-3587. [CrossRef]

48. Brandes, N.; Schmitt, S.; Jakob, U. Thiol-based redox switches in eukaryotic proteins. Antioxid. Redox. Signal. 2009, 11, 997-1014. [CrossRef]

49. Kultz, D. Molecular and evolutionary basis of the cellular stress response. Annu. Rev. Physiol. 2005, 67, 225-257. [CrossRef]

50. Madeo, F.; Frohlich, E.; Ligr, M.; Grey, M.; Sigrist, S.J.; Wolf, D.H.; Frohlich, K.U. Oxygen stress: A regulator of apoptosis in yeast. J. Cell Biol. 1999, 145, 757-767. [CrossRef]

51. Pham-Huy, L.A.; He, H.; Pham-Huy, C. Free radicals, antioxidants in disease and health. Int. J. Biomed. Sci. 2008, 4, 89-96. [PubMed]

52. Pierce, G.B.; Parchment, R.E.; Lewellyn, A.L. Hydrogen peroxide as a mediator of programmed cell death in the blastocyst. Differentiation 1991, 46, 181-186. [CrossRef] [PubMed]

53. Pena, L.B.; Barcia, R.A.; Azpilicueta, C.E.; Mendez, A.A.; Gallego, S.M. Oxidative post translational modifications of proteins related to cell cycle are involved in cadmium toxicity in wheat seedlings. Plant Sci. 2012, 196, 1-7. [CrossRef] [PubMed]

54. Srinivas Bharath, M.M. Post-translational oxidative modifications of mitochondrial complex I (NADH: Ubiquinone oxidoreductase): Implications for pathogenesis and therapeutics in human diseases. J. Alzheimers Dis. 2017, 60, S69-S86. [CrossRef] 
55. Chen, Y.; Hoehenwarter, W. Changes in the phosphoproteome and metabolome link early signaling events to rearrangement of photosynthesis and central metabolism in salinity and oxidative stress response in Arabidopsis. Plant Physiol. 2015, 169, 3021-3033. [CrossRef]

56. Preidis, G.A.; Keaton, M.A.; Campeau, P.M.; Bessard, B.C.; Conner, M.E.; Hotez, P.J. The undernourished neonatal mouse metabolome reveals evidence of liver and biliary dysfunction, inflammation, and oxidative stress. J. Nutr. 2014, 144, 273-281. [CrossRef]

57. Ishikawa, T.; Takahara, K.; Hirabayashi, T.; Matsumura, H.; Fujisawa, S.; Terauchi, R.; Uchimiya, H.; Kawai-Yamada, M. Metabolome analysis of response to oxidative stress in rice suspension cells overexpressing cell death suppressor Bax inhibitor-1. Plant Cell Physiol. 2010, 51, 9-20. [CrossRef]

58. Noctor, G.; Mhamdi, A.; Foyer, C.H. Oxidative stress and antioxidative systems: Recipes for successful data collection and interpretation. Plant Cell Environ. 2016, 39, 1140-1160. [CrossRef]

59. Spura, J.; Reimer, L.C.; Wieloch, P.; Schreiber, K.; Buchinger, S.; Schomburg, D. A method for enzyme quenching in microbial metabolome analysis successfully applied to gram-positive and gram-negative bacteria and yeast. Anal. Biochem. 2009, 394, 192-201. [CrossRef]

60. Prokai, L.; Stevens, S.M., Jr.; Rauniyar, N.; Nguyen, V. Rapid label-free identification of estrogen-induced differential protein expression in vivo from mouse brain and uterine tissue. J. Proteome Res. 2009, 8, 3862-3871. [CrossRef]

61. Vizcaino, J.A.; Deutsch, E.W.; Wang, R.; Csordas, A.; Reisinger, F.; Rios, D.; Dianes, J.A.; Sun, Z.; Farrah, T.; Bandeira, N.; et al. ProteomeXchange provides globally coordinated proteomics data submission and dissemination. Nat. Biotechnol. 2014, 32, 223-226. [CrossRef] [PubMed]

62. Tutorials: Understanding the P-Value of Overlap Statistic in IPA. Available online: https:/ tv.qiagenbioinformatics.com/video/ 19605716/understanding-the-p-value-of (accessed on 8 November 2020). 